\title{
CO-induced ring-slippage reactions of molybdenocene and tungstenocene carbonyl complexes. Electrochemical and elevated-pressure infrared evidence for an electron-transfer catalysis
}

\author{
Sigrid Mönkeberg, Edith van Raaij, Herbert Kiesele * \\ and Hans-Herbert Brintzinger ** \\ Fakultät für Chemie, Universität Konstanz, D-7750 Konstanz (F.R.G.)
}

\begin{abstract}
Infrared studies at a $\mathrm{CO}$ pressure of 120 bar show $\left(\eta^{5}-\mathrm{C}_{5} \mathrm{H}_{5}\right)_{2} \mathrm{~W}(\mathrm{CO})$ to be completely resistant to an excess of $\mathrm{CO}$ in the absence of oxidants, but cyclovoltammetric measurements with this complex and with $\left(\eta^{3}-\mathrm{C}_{5} \mathrm{H}_{5}\right)\left(\eta^{5}-\mathrm{C}_{5} \mathrm{H}_{5}\right) \mathrm{W}(\mathrm{CO})_{2}$ in THF solution at $0^{\circ} \mathrm{C}$ indicate that the ring-slipped dicarbonyl complex is catalytically generated by a one-electron oxidation of the tungstenocene monocarbonyl under $\mathrm{CO}$ at ambient pressure. Similar results are found for the reaction of $\left(\eta^{5}-\mathrm{C}_{5} \mathrm{H}_{5}\right)_{2} \mathrm{Mo}(\mathrm{CO})$ with $\mathrm{CO}$.
\end{abstract}

\section{Introduction}

Among an increasing number of 'ring-slipped', i.e., of $\eta^{3}$ - and $\eta^{1}$-coordinated cyclopentadienyl and indenyl complexes discussed recently ${ }^{* * *}$, the tungsten compound $\left(\eta^{3}-\mathrm{C}_{5} \mathrm{H}_{5}\right)\left(\eta^{5}-\mathrm{C}_{5} \mathrm{H}_{5}\right) \mathrm{W}(\mathrm{CO})_{2}[2,3]$ still appears to represent the only example of an $\eta^{3}$-cyclopentadienyl geometry established by X-ray crystallography [4]. While this compound, when pure, is thermally quite stable and even sublimable in vacuo [2], attempts to repeat its synthesis have met with varying degrees of success [3,5]. We thought it worthwhile, therefore, to reinvestigate the conditions of its formation from the tungstenocene monocarbonyl complex $\left(\eta^{5}-\mathrm{C}_{5} \mathrm{H}_{5}\right)_{2} \mathrm{~W}(\mathrm{CO})$ and an excess of CO. Having recently encountered an efficient electron-transfer catalysis for a related $\eta^{5} \rightarrow \eta^{3}$ ring-slippage reaction of an ansa-chromocene carbonyl complex, $\left(\mathrm{CH}_{3}\right)_{4} \mathrm{C}_{2}\left(\eta^{5}-\mathrm{C}_{5} \mathrm{H}_{4}\right)_{2} \mathrm{Cr}(\mathrm{CO})+\mathrm{CO} \rightarrow\left(\mathrm{CH}_{3}\right)_{4} \mathrm{C}_{2}\left(\eta^{3}-\mathrm{C}_{5} \mathrm{H}_{4}\right)\left(\eta^{5}-\mathrm{C}_{5} \mathrm{H}_{4}\right) \mathrm{Cr}(\mathrm{CO})_{2}[6,7]$,

* Present address: Drägerwerk AG, D-2400 Lübeck 1 (F.R.G.)

** To whom correspondence should be addressed.

*** For a recent review of $\eta^{3}$ - and $\eta^{1}$-coordinated cyclopentadienyl and indenyl complexes see ref. 1 . 
we have now studied redox reactions of molybdenocene and tungstenocene carbonyl complexes and their role in ring-slippage reactions of these compounds.

\section{Experimental}

Samples of $\left(\mathrm{C}_{5} \mathrm{H}_{5}\right)_{2} \mathrm{~W}(\mathrm{CO})[8],\left(\mathrm{C}_{5} \mathrm{H}_{5}\right)_{2} \mathrm{~W}(\mathrm{CO})_{2}[3],\left(\mathrm{C}_{5} \mathrm{H}_{5}\right)_{2} \mathrm{WCl}_{2}$ [9] and $\left(\mathrm{C}_{5} \mathrm{H}_{5}\right)_{2} \mathrm{Mo}(\mathrm{CO})[8]$ were prepared as previously described: except for $\left(\mathrm{C}_{5} \mathrm{H}_{5}\right)_{2} \mathrm{WCl}_{2}$, these compounds and their solutions were handled with strict exclusion of air, either in a glovebox or on a vacuum-line. Cyclovoltammetry measurements were made with $2.5 \times 10^{-4}-2.5 \times 10^{-3} M$ solutions in anhydrous THF containing $0.1 M$ tetrabutylammonium hexafluorophosphate $\left(\mathrm{TBA}^{+} \mathrm{PF}_{6}{ }^{-\cdots}\right)$ by use of an electrochemical cell with an internal drying column [10], as described previously [11,12]. Potentials were measured with IR compensation vs, an $\mathrm{Ag} / \mathrm{AgNO}$ (sat) $\mathrm{TBA}^{+} \mathrm{PF}_{6}{ }^{-\cdots}(0.1 \mathrm{M}) / \mathrm{THF}\left(25^{\circ} \mathrm{C}\right)$ reference electrode. These potentials were referred to SCE by adding a correction offset $\Delta E=0.16-\left(E_{\mathrm{p}}\left(\mathrm{OX}_{\mathrm{Cp}_{2} \mathrm{Fe}_{\mathrm{e}}}\right)+\right.$

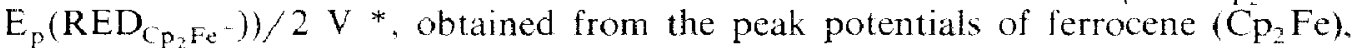
which was added afterwards in small amounts to each solution studied.

Infrared spectra of the tungstenocene and molybdenocene carbonyl compounds in toluene solution and of the reaction mixture during their treatment with $\mathrm{CO}$ were recorded by use of an IR cell with internal circulation suitable for isothermic and isobaric measurements under elevated gas pressures. The absorbance spectra obtained were corrected to constant path lengths and by subtraction of the solvent spectrum as previously described [14].

\section{Results and discussion}

1. Redox Reactions of $\left(\eta^{5}-C_{5} H_{5}\right)_{2} W+(C O)$. Cyclovoltammograms of $\left(\mathrm{C}_{5} \mathrm{H}_{5}\right)_{2} \mathrm{~W}$ (CO) show a partly reversible oxidation at a potential of ca. $-0.74 \mathrm{~V}$ and an irreversible reduction wave at a rather low potential of ca. $-3.2 \mathrm{~V}$ (see Fig. 1 ).

The oxidation of $\left(\mathrm{C}_{5} \mathrm{H}_{5}\right)_{2} \mathrm{~W}(\mathrm{CO})$ at peak $A_{\mathrm{M}}^{\prime}\left(E_{\mathrm{P}},\left(A_{\mathrm{M}}^{\prime}\right)=-0.62 \mathrm{~V}, E_{\mathrm{P}}\left(A_{\mathrm{M}}\right)=\right.$ $-0.86 \mathrm{~V}$ at $0.5 \mathrm{~V} / \mathrm{s}$ ) appears to be a sluggish one-electron transfer (eq. 1), with interference from a slow homogeneous reaction. At low sweep rates $(0.05 \mathrm{~V} / \mathrm{s})$, the peak current ratio of the associated reduction peak $A_{\mathrm{M}}$ is $i_{\mathrm{p}}\left(A_{\mathrm{M}}\right) / i_{\mathrm{p}}\left(A_{\mathrm{M}}^{\prime}\right)=0.8 * *$. This observation, as well as the appearance of two additional reduction peaks $B_{M}$ and $C_{\mathrm{M}}\left(E_{\mathrm{P}}\left(B_{\mathrm{M}}\right)=-1.79 \mathrm{~V}, E_{\mathrm{P}}\left(C_{\mathrm{M}}=-2.00 \mathrm{~V}\right)\right.$ after oxidation at $A_{\mathrm{M}}^{\prime}$. indicates a partial decay of the cation $\left(\mathrm{C}_{5} \mathrm{H}_{5}\right)_{2} \mathrm{~W}(\mathrm{CO})^{+}$, which could involve either uptake of a solvent (Slv) ligand (eq. 2), a ligand disproportionation to $\left(\mathrm{C}_{5} \mathrm{H}_{5}\right)_{2} \mathrm{~W}(\mathrm{CO})_{2}{ }^{+}$and $\left(\mathrm{C}_{5} \mathrm{H}_{5}\right)_{2} \mathrm{~W}(\mathrm{Slv})^{+}$(eq. 3), a redox disproportionation of the $W^{\text {III }}$ cation $\left(\mathrm{C}_{5} \mathrm{H}_{5}\right)_{2} \mathrm{~W}(\mathrm{CO})^{+}$to $\left(\mathrm{C}_{5} \mathrm{H}_{5}\right)_{2} \mathrm{~W}(\mathrm{CO})$ and a $\mathrm{W}^{\mathrm{N}}$ species (eq. 4), or a combination of these.

$\left(\mathrm{C}_{5} \mathrm{H}_{2}\right)_{2} \mathrm{~W}(\mathrm{CO}) \underset{A_{\mathrm{M}}}{\stackrel{A_{\mathrm{M}}^{\prime}}{\rightleftharpoons}}\left(\mathrm{C}_{5} \mathrm{H}_{5}\right) \mathrm{W}(\mathrm{CO})^{+}+\mathrm{e}$

* The standard potential of the ferrocene/ferricinium couple in THF/TBA ${ }^{*} \mathrm{PF}_{6}^{-}$solution, $E\left(\mathrm{Cp}_{2} \mathrm{Fe} / \mathrm{Cp}_{2} \mathrm{Fe}^{+}\right) 0.16 \mathrm{~V}$ vs. SCE was taken from ref. 13 . The correction offset $\Delta E$ was in the range +0.26 to $+0.30 \mathrm{~V}$.

** At higher sweep rates. the reduction peak becomes too broad for quantitative evaluation. 


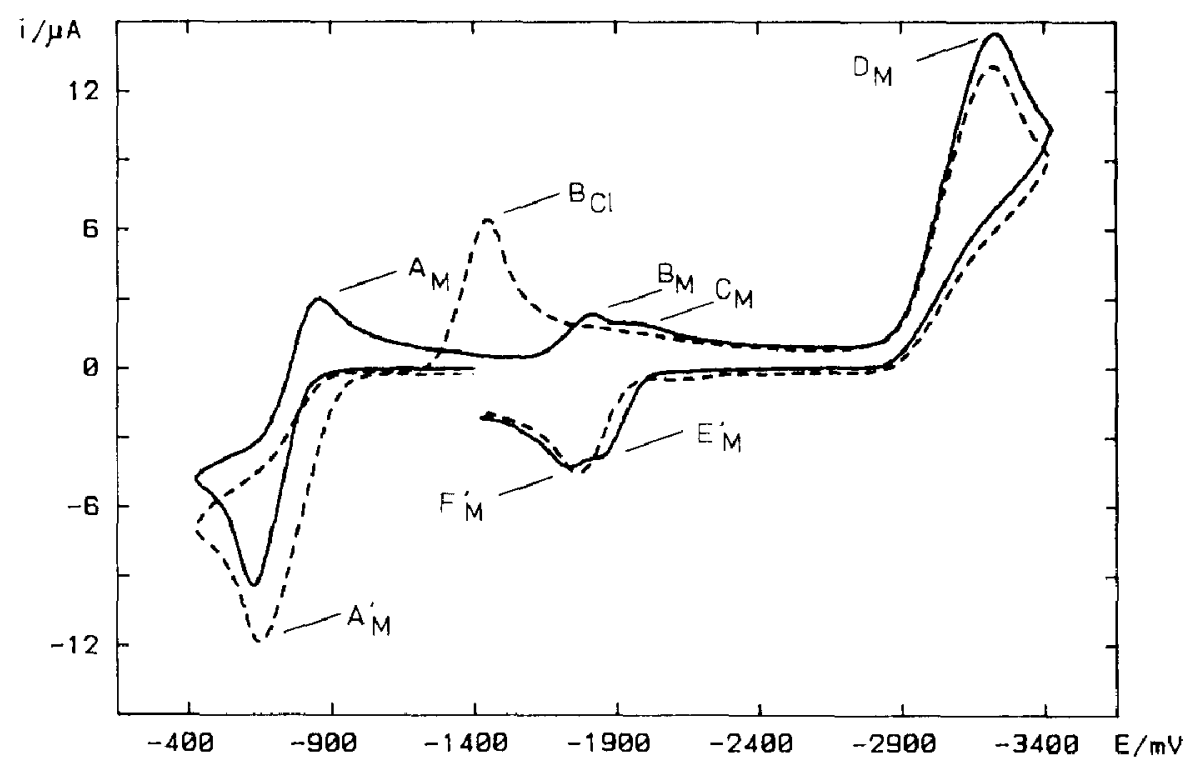

Fig. 1. Cyclic voltammograms of $\left(\mathrm{C}_{5} \mathrm{H}_{5}\right)_{2} \mathrm{~W}(\mathrm{CO}), 2.5 \times 10^{-3} \mathrm{M}$ in THF with $0.1 \mathrm{M} \mathrm{TBA}^{+} \mathrm{PF}_{6}^{-}$, at $0^{\circ} \mathrm{C}$ under $\mathrm{Ar}$ (solid line) and after addition of $\mathrm{TBA}^{+} \mathrm{Cl}^{-}$ca. $10^{-2} \mathrm{M}$ (dashed line). Sweep rate $0.5 \mathrm{~V} / \mathrm{s}$.

$$
\begin{aligned}
& \left(\mathrm{C}_{5} \mathrm{H}_{5}\right)_{2} \mathrm{~W}(\mathrm{CO})^{+}+\mathrm{Slv} \rightleftharpoons\left(\mathrm{C}_{5} \mathrm{H}_{5}\right)_{2} \mathrm{~W}(\mathrm{CO})(\mathrm{Slv})^{+} \\
& 2\left(\mathrm{C}_{5} \mathrm{H}_{2}\right)_{2} \mathrm{~W}(\mathrm{CO})^{+}+\mathrm{Slv} \rightleftharpoons\left(\mathrm{C}_{5} \mathrm{H}_{5}\right)_{2} \mathrm{~W}(\mathrm{CO})_{2}{ }^{+}+\left(\mathrm{C}_{5} \mathrm{H}_{5}\right)_{2} \mathrm{~W}(\mathrm{Slv})^{+} \\
& 2\left(\mathrm{C}_{5} \mathrm{H}_{5}\right)_{2} \mathrm{~W}(\mathrm{CO})^{+}+\mathrm{Slv} \rightleftharpoons\left(\mathrm{C}_{5} \mathrm{H}_{5}\right)_{2} \mathrm{~W}(\mathrm{CO})+\left(\mathrm{C}_{5} \mathrm{H}_{5}\right)_{2} \mathrm{~W}(\mathrm{CO})(\mathrm{Slv})^{2+}
\end{aligned}
$$

Addition of $\mathrm{TBA}^{+} \mathrm{Cl}^{-}$(ca. $0.1 M$ ) to these solutions causes an increase in peak current at oxidation peak $A_{\mathrm{M}}^{\prime}$ by about $25 \%$. Reduction peak $A_{\mathrm{M}}$ and the secondary reduction peaks $B_{\mathrm{M}}$ and $C_{\mathrm{M}}$ are now completely absent; instead, a new peak $B_{\mathrm{Cl}}$ is present at $E_{\mathrm{P}}\left(B_{\mathrm{C} 1}\right)=-1.50 \mathrm{~V}$. ${ }^{*}$ These observations indicate parallel EC and ECE processes for the oxidation of $\left(\mathrm{C}_{5} \mathrm{H}_{5}\right)_{2} \mathrm{~W}(\mathrm{CO})$, induced by the presence of excess $\mathrm{Cl}^{-}$(eq. 5). These processes appears to be chemically reversible, with reduction at peak $B_{\mathrm{Cl}}$ regenerating neutral monocarbonyl, as indicated by the practically unchanged peak currents at reduction peak $D_{\mathrm{M}}$ and on a second sweep through oxidation peak $A_{\mathrm{M}}^{\prime}$.

$\left(\mathrm{C}_{5} \mathrm{H}_{5}\right)_{2} \mathrm{~W}(\mathrm{CO})^{+}+\mathrm{Cl}^{-} \rightleftharpoons\left(\mathrm{C}_{5} \mathrm{H}_{5}\right)_{2} \mathrm{~W}(\mathrm{CO}) \mathrm{Cl}^{+}+\mathrm{e}^{-}$

Reduction of $\left(\mathrm{C}_{5} \mathrm{H}_{5}\right)_{2} \mathrm{~W}(\mathrm{CO})$ occurs at peak $D_{\mathrm{M}}\left(E_{\mathrm{P}}\left(D_{\mathrm{M}}\right)=-3.2 \mathrm{~V}\right.$, at 0.5 $\mathrm{V} / \mathrm{s}$ ). The peak current at $D_{\mathrm{M}}$ is about 1.5 times greater than that of oxidation peak $A^{\prime}$. This increased reduction current could be due to the kinetically hindered formation of the dianion $\left(\mathrm{C}_{5} \mathrm{H}_{5}\right)_{2} \mathrm{~W}(\mathrm{CO})^{2-}$, possibly an $\eta^{3}, \eta^{5}$-coordination 18-electron species, by two-electron reduction of $\left(\mathrm{C}_{5} \mathrm{H}_{5}\right)_{2} \mathrm{~W}(\mathrm{CO})$ or by redox-disproportionation of $\left(\mathrm{C}_{5} \mathrm{H}_{5}\right)_{2} \mathrm{~W}(\mathrm{CO})^{-}$. Reduction at $D_{\mathrm{M}}$ is irreversible; two unresolved, irreversible oxidation peaks $E_{\mathrm{M}}^{\prime}$ and $F_{\mathrm{M}}^{\prime}$, with peak potentials close to $-1.8 \mathrm{~V}$ (at $0.5 \mathrm{~V} / \mathrm{s}$ ), are observed after reduction at $D_{\mathrm{M}}$, indicating a fast decay of the species formed at $D_{\mathrm{M}}$.

\footnotetext{
* An additional reduction peak $C_{\mathrm{Cl}}$ with $E_{\mathrm{P}}\left(C_{\mathrm{Cl}}\right)=-1.97 \mathrm{~V}$ is observed after extended electrolysis at $+0.3 \mathrm{~V}$.
} 


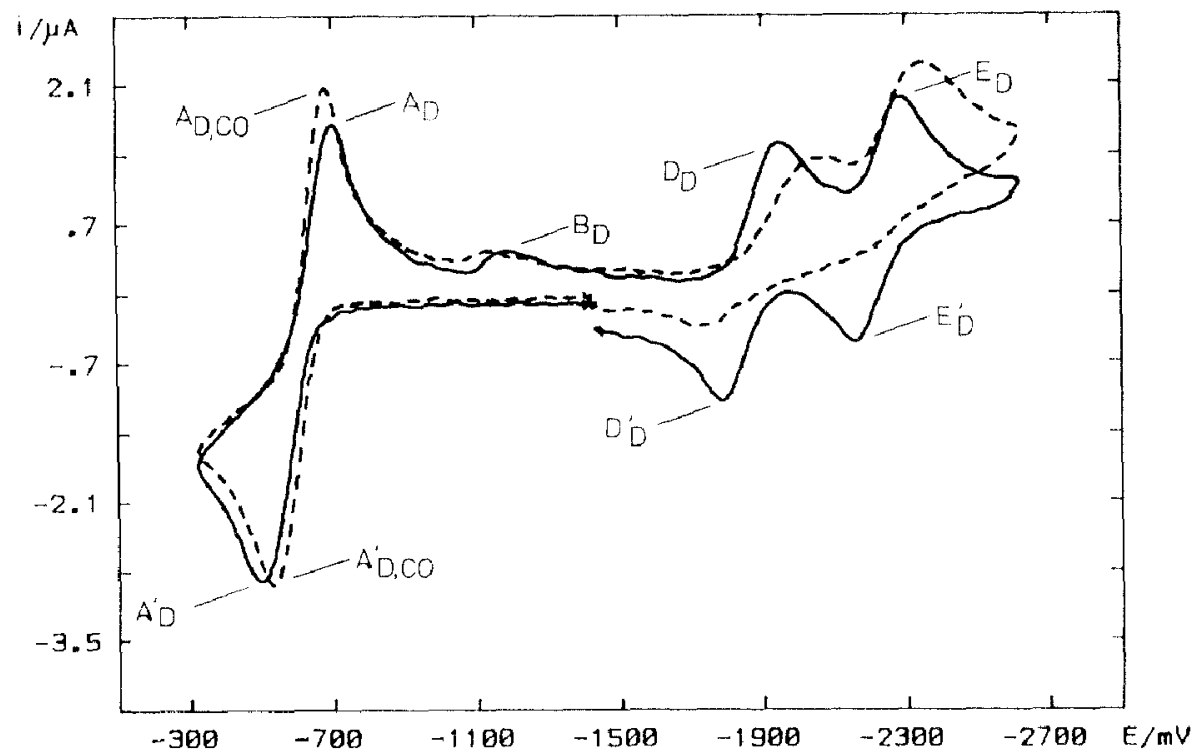

Fig. 2. Cyclic voltammograms of $\left(\mathrm{C}_{5} \mathrm{H}_{5}\right)_{2} \mathrm{~W}(\mathrm{CO})_{2}$, ca. $2.5 \times 10^{-4} M$ in THF with $0.1 \mathrm{M}^{-4} \mathrm{TBA}^{+} \mathrm{PF}_{6}$, at $0^{\circ} \mathrm{C}$ under Ar (solid line) and under $\mathrm{CO}$ (dashed line). Sweep rate $0.5 \mathrm{~V} / \mathrm{s}$.

2. Redox Reactions of $\left(\eta^{3}-C_{5} H_{5}\right)\left(\eta^{5}-C_{5} H_{5}\right) W(C O)_{2}$. Cyclovoltammograms of the tungstenocene dicarbonyl complex show an essentially reversible oxidation wave around $-0.6 \mathrm{~V}$ and two partially reversible reduction waves around -1.9 and -2.2 V (see Fig. 2) *.

Oxidation of the dicarbonyl complex at peak $A_{\mathrm{D}}^{\prime}\left(E_{\mathrm{P}}\left(A_{\mathrm{D}}^{\prime}\right)=-0.50 \mathrm{~V}, E_{\mathrm{P}}\right.$ $\left(A_{\mathrm{D}}\right)=-0.70 \mathrm{~V}$ at $\left.0.5 \mathrm{~V} / \mathrm{s}\right)$ occurs at a potential more positive by $120 \mathrm{mV}$ than that for $\left(\mathrm{C}_{5} \mathrm{H}_{5}\right)_{2} \mathrm{~W}(\mathrm{CO})$. The relatively high peak current at oxidation peak $\mathrm{A}_{\mathrm{D}}^{\prime}$ suggests a two-electron oxidation. Owing to its 18 -electron configuration, a dication $\left(\eta^{5}-\mathrm{C}_{5} \mathrm{H}_{5}\right)_{2} \mathrm{~W}(\mathrm{CO})_{2}{ }^{2+}$ could be the favoured product of oxidation at $A_{\mathrm{D}}^{\prime}$. The reversibility of this oxidation is temperature-dependent: At $25^{\circ} \mathrm{C}$, the peak current at the conjugate reduction peak $A_{\mathrm{D}}$ is less than half of that at oxidation peak $A_{\mathrm{D}}^{\prime}$. At $0^{\circ} \mathrm{C}$, however, the peak current ratio $i_{\mathrm{p}}\left(A_{\mathrm{D}}\right) /\left(i_{\mathrm{p}}\left(A_{\mathrm{D}}^{\prime}\right)\right.$ is about 0.9 at $1 \mathrm{~V} / \mathrm{s}$. Furthermore, under a $\mathrm{CO}$ atmosphere, this oxidation wave becomes practically reversible, with $i_{\mathrm{p}}\left(A_{\mathrm{D}}\right) / i_{\mathrm{p}}\left(A_{\mathrm{D}}^{\prime}\right) \approx 1$; its peak separation is then $140 \mathrm{mV}$ at $0.5 \mathrm{~V} / \mathrm{s}$ (see Fig. 2). This peak separation is substantially larger than the $30 \mathrm{mV}$ required for the formation of the dication $\left(\mathrm{C}_{5} \mathrm{H}_{5}\right)_{2} \mathrm{~W}(\mathrm{CO})_{2}{ }^{2+}$ by a direct uninhibited two-electron transfer [15], and indicates the superposition of two hindered single-electron transfer steps with similar reduction potentials. Simulation studies by the implicit Crank-Nicolson method [16] show that with heterogeneous standard rate constants of the order of $1 \mathrm{~cm} \mathrm{sec}^{-1}$, the observed peak shape is best reproduced by assigning to the two successive oxidation steps (eq. 6 and 7) potential values of -0.64 and $-0.74 \mathrm{~V}$, respectively. ${ }^{*}$ These values would require the disproportionation equilibrium for the monocation shown in eq. 8, with an equilibrium constant $K_{\text {disp }} \approx$ $70 * *$.

* A small oxidation peak $C_{\mathrm{D}}^{\prime}\left(E_{\mathrm{P}}\left(C_{\mathrm{D}}^{\prime}\right)=+0.26 \mathrm{~V}\right.$ at $\left.0.5 \mathrm{~V} / \mathrm{s}\right)$ in broad and totally irreversible. Any species arising at this oxidation peak thus appears to be quite unstable.

** Whether such a disproportionation occurs at a finite rate cannot be determined from our data. 
$\left(\mathrm{C}_{5} \mathrm{H}_{5}\right)_{2} \mathrm{~W}(\mathrm{CO})_{2} \rightleftharpoons\left(\mathrm{C}_{5} \mathrm{H}_{5}\right)_{2} \mathrm{~W}(\mathrm{CO})_{2}{ }^{+}+\mathrm{e}^{-}$

$\left(\mathrm{C}_{5} \mathrm{H}_{5}\right)_{2} \mathrm{~W}(\mathrm{CO})_{2}{ }^{+} \rightleftharpoons\left(\mathrm{C}_{5} \mathrm{H}_{5}\right)_{2} \mathrm{~W}(\mathrm{CO})_{2}{ }^{2+}+\mathrm{e}^{-}$

$2\left(\mathrm{C}_{5} \mathrm{H}_{5}\right)_{2} \mathrm{~W}(\mathrm{CO})_{2}{ }^{+} \rightleftharpoons\left(\mathrm{C}_{5} \mathrm{H}_{5}\right)_{2} \mathrm{~W}(\mathrm{CO})_{2}+\left(\mathrm{C}_{5} \mathrm{H}_{5}\right)_{2} \mathrm{~W}(\mathrm{CO})_{2}{ }^{2+}$

The $\eta^{3} \leftrightarrow \eta^{5}$ conversion of one of the ring ligands would most likely occur at the level of the monocation, so that the overall process at oxidation wave $A_{\mathrm{D}}^{\prime} / A_{\mathrm{D}}$ would again be of ECE type. If this is indeed the case, the $\eta^{3} \leftrightarrow \eta^{5}$ interconversion would have to be faster than the time scale of the electrochemical experiment, otherwise this oxidation wave would have an entirely different shape (cf. ref. 15).

Reduction of $\left(\mathrm{C}_{5} \mathrm{H}_{5}\right)_{2} \mathrm{~W}(\mathrm{CO})_{2}$ gives rise to two somewhat broadened peaks $D_{\mathrm{D}}$ and $E_{\mathrm{D}}$ with associated reoxidation peaks $D_{\mathrm{D}}^{\prime}$ and $E_{\mathrm{D}}^{\prime}\left(E_{\mathrm{P}}\left(D_{\mathrm{D}}\right)=-1.94 \mathrm{~V}, E_{\mathrm{P}}\right.$ $\left(D_{\mathrm{D}}^{\prime}\right)=-1.78 \mathrm{~V}, E_{\mathrm{P}}\left(E_{\mathrm{D}}\right)=-2.28 \mathrm{~V}, E_{\mathrm{P}}\left(E_{\mathrm{D}}^{\prime}\right)=-2.15 \mathrm{~V}$ at $\left.0.5 \mathrm{~V} / \mathrm{s}\right)$. At sweep rates between 0.1 and $1 \mathrm{~V} / \mathrm{s}$, the peak currents at reduction peaks $D_{\mathrm{D}}$ and $E_{\mathrm{D}}$ are of comparable magnitude, as are those of the associated reoxidation peaks $D_{\mathrm{D}}^{\prime}$ and $E_{\mathrm{D}}^{\prime}$. These observations suggest that the two reduction waves are caused by two successive one-electron reductions, which would generate the anions $\left(\mathrm{C}_{5} \mathrm{H}_{5}\right)_{2} \mathrm{~W}$ $(\mathrm{CO})_{2}{ }^{-}$and $\left(\mathrm{C}_{5} \mathrm{H}_{5}\right)_{2} \mathrm{~W}(\mathrm{CO})_{2}{ }^{2-}$, respectively, both of which appear to have half-lives of the order of several seconds *. In the presence of $\mathrm{CO}$ gas both reduction peaks become completely irreversible; apparently, the anionic particles generated at these peaks are rapidly decomposed by an excess of CO. Formation of $\left(\mathrm{C}_{5} \mathrm{H}_{5}\right) \mathrm{W}(\mathrm{CO})_{3}{ }^{-}$ or $\left[\left(\mathrm{C}_{5} \mathrm{H}_{5}\right) \mathrm{W}(\mathrm{CO})_{3}\right]_{2}$ would provide a possible mode of stabilization of these low-valent tungsten complexes **.

3. Conversion of $\left(\eta^{5}-C_{5} H_{5}\right) W(C O)$ to $\left(\eta^{3}-C_{5} H_{5}\right)\left(\eta^{5}-C_{5} H_{5}\right) W(C O)_{2}$ by electrolysis under $\mathrm{CO}$. While the changes in the cyclovoltammograms of $\left(\mathrm{C}_{5} \mathrm{H}_{5}\right)_{2} \mathrm{~W}(\mathrm{CO})_{2}$ caused by the presence of an excess of $\mathrm{CO}$ are unsurprising, a number of unexpected changes are observed when THF solutions of $\left(\mathrm{C}_{5} \mathrm{H}_{5}\right)_{2} \mathrm{~W}(\mathrm{CO})$ are studied under an atmosphere of $\mathrm{CO}$ : An oxidative sweep now produces, closely adjacent to each other, the oxidation peaks $A_{\mathrm{M}}^{\prime}$ and $A_{\mathrm{D}}^{\prime}$ of both the mono- and the di-carbonyl complex (cf. Fig. 3). The peak current ratio for these two peaks strongly depends on the sweep rate: at $1 \mathrm{~V} / \mathrm{s}$ we find $i_{\mathrm{P}}\left(A_{\mathrm{M}}^{\prime}\right) / i_{\mathrm{P}}\left(A_{\mathrm{D}}^{\prime}\right)>1$ (i.e., a preponderance of monocarbonyl); at $0.05 \mathrm{~V} / \mathrm{s}$ the dicarbonyl peak dominates with $i_{\mathrm{P}}\left(A_{\mathrm{M}}^{\prime}\right) / i_{\mathrm{P}}$ $\left(A_{\mathrm{D}}^{\prime}\right)<0.5$.

These observations can be most simply accounted for in terms of a catalytic formation of the tungstenocene dicarbonyl from the monocarbonyl complex and an excess of $\mathrm{CO}$, induced by an electron transfer from the neutral monocarbonyl starting material to the dicarbonyl cation (eq. 9, 10). This assignment is confirmed by the appearance of the characteristic pair of reduction peaks of the tungstenocene dicarbonyl complex, $D_{\mathrm{D}}$ and $E_{\mathrm{D}}$, whenever solutions of $\left(\mathrm{C}_{5} \mathrm{H}_{5}\right)_{2} \mathrm{~W}(\mathrm{CO})$ under $\mathrm{CO}$ are subjected to a potential close to that of oxidation peak $A_{M}$ and subsequently to a reductive backsweep.

$\left(\mathrm{C}_{5} \mathrm{H}_{5}\right)_{2} \mathrm{~W}(\mathrm{CO})^{+}+\mathrm{CO} \rightarrow\left(\mathrm{C}_{5} \mathrm{H}_{5}\right)_{2} \mathrm{~W}(\mathrm{CO})_{2}^{+}$

$\left(\mathrm{C}_{5} \mathrm{H}_{5}\right)_{2} \mathrm{~W}(\mathrm{CO})_{2}{ }^{+}+\left(\mathrm{C}_{5} \mathrm{H}_{5}\right)_{2} \mathrm{~W}(\mathrm{CO}) \rightarrow\left(\mathrm{C}_{5} \mathrm{H}_{5}\right)_{2} \mathrm{~W}(\mathrm{CO})_{2}+\left(\mathrm{C}_{5} \mathrm{H}_{5}\right)_{2} \mathrm{~W}(\mathrm{CO})^{+}$

* Closer inspection of the peak current ratios, $i_{\mathrm{p}}\left(D_{\mathrm{D}}\right) / i_{\mathrm{P}}\left(E_{\mathrm{D}}\right)>1$ and $i_{\mathrm{P}}\left(D_{\mathrm{D}}^{\prime}\right) / i_{\mathrm{P}}\left(E_{\mathrm{D}}^{\prime}\right)<1$, suggests a slow consecutive reaction.

** A strong oxidation wave at ca. $-0.58 \mathrm{~V}$ that which appears after reduction of $\left(\mathrm{C}_{5} \mathrm{H}_{5}\right)_{2} \mathrm{~W}(\mathrm{CO})_{2}$ under $\mathrm{CO}$ can be assigned to $\left(\mathrm{C}_{5} \mathrm{H}_{5}\right)_{2} \mathrm{~W}(\mathrm{CO})_{3}^{-}[17,18]$. 


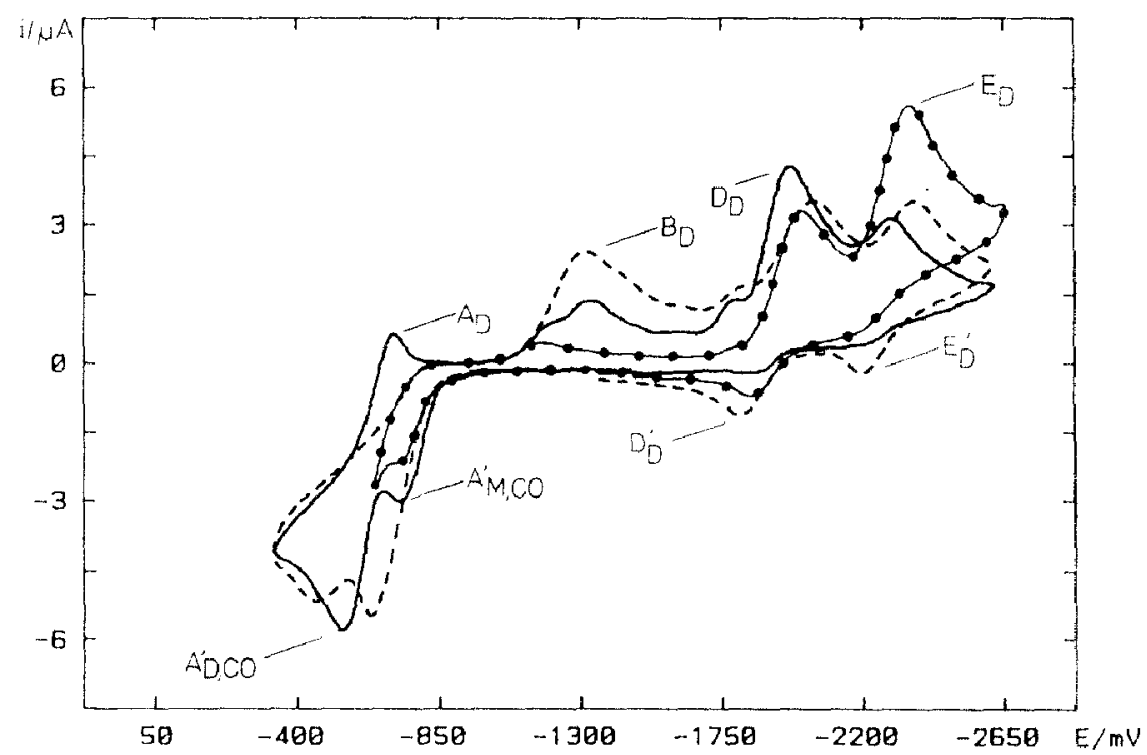

Fig. 3. Cyclic voltammograms of $\left(\mathrm{C}_{5} \mathrm{H}_{5}\right)$ W(CO), $2.5 \times 10^{-3} M$ in THF with $0.1 M \mathrm{TBA}^{+} \mathrm{PF}_{6}^{-}$, at $0^{\circ} \mathrm{C}$ under $\mathrm{CO}$ at sweep rates of $0.05 \mathrm{~V} / \mathrm{s}$ (solid line) and $1.0 \mathrm{~V} / \mathrm{s}$ (dashed line). Dotted line corresponds to potential sweep $(0.5 \mathrm{~V} / \mathrm{s})$ with reversal at $-0.6 \mathrm{~V}$. Currents at different sweep rates sealed to that at 0.5 $\mathrm{V} / \mathrm{s}$.

A complicating interference by the dication $\left(\mathrm{C}_{5} \mathrm{H}_{5}\right)_{2} \mathrm{~W}(\mathrm{CO})_{2}{ }^{2+}$ with this simple electron-transfer catalysis cycle is indicated by the non-reversibility of the oxidation peaks $A_{\mathrm{M}}^{\prime}$ and $A_{\mathrm{D}}^{\prime}$ in these reaction systems. While the oxidation waves of both $\left(\mathrm{C}_{5} \mathrm{H}_{5}\right)_{2} \mathrm{~W}(\mathrm{CO})$ and $\left(\mathrm{C}_{5} \mathrm{H}_{5}\right)_{2} \mathrm{~W}(\mathrm{CO})_{2}$ are essentially reversible under an atmosphere of $\mathrm{Ar}$, and the latter even more so under an atmosphere of $\mathrm{CO}$, there is a conspicuous absence of any reduction peak assignable to either $\left(\mathrm{C}_{5} \mathrm{H}_{5}\right)_{2} \mathrm{~W}(\mathrm{CO})^{+}$or $\left(\mathrm{C}_{5} \mathrm{H}_{5}\right)_{2} \mathrm{~W}(\mathrm{CO})_{2}{ }^{2+}$ in a reductive back sweep following the oxidative generation of these two particles in a $\mathrm{CO}$-saturated solution of $\left(\mathrm{C}_{5} \mathrm{H}_{5}\right)_{2} \mathrm{~W}(\mathrm{CO})$ (see Fig. 3). Instead, reduction peak $B_{\mathrm{D}}$, assigned above to some ligand exchange product formed from $\left(\mathrm{C}_{5} \mathrm{H}_{5}\right)_{2} \mathrm{~W}(\mathrm{CO})_{2}{ }^{2+}$, becomes quite pronounced, particularly at high sweep rates $(1 \mathrm{~V} / \mathrm{s})$. At lower sweep rates $(0.05 \mathrm{~V} / \mathrm{s})$, this secondary reduction peak $B_{\mathrm{D}}$ is considerably smaller, while the dicarbonyl reduction peak $A_{\mathrm{D}}$ regains some of its original peak current.

At present, we can only state that in solutions which contain $\left(\mathrm{C}_{5} \mathrm{H}_{5}\right){ }_{2} \mathrm{~W}(\mathrm{CO})^{+}$as well as $\left(\mathrm{C}_{5} \mathrm{H}_{5}\right)_{2} \mathrm{~W}(\mathrm{CO})_{2}{ }^{2+}$ both cations are apparently converted into some as yet unidentified species which, upon reduction at peak $B_{\mathrm{D}}$, regenerates the neutral dicarbonyl complex $\left(\mathrm{C}_{5} \mathrm{H}_{5}\right)_{2} \mathrm{~W}(\mathrm{CO})_{2}$, as indicated by the fact that the dicarbonyl reduction peaks $D_{\mathrm{D}}$ and $E_{\mathrm{D}}$ have their normal appearance.

This complication occurs, however, only after oxidative generation of $\left(\mathrm{C}_{5} \mathrm{H}_{5}\right)_{2} \mathrm{~W}(\mathrm{CO})_{2}{ }^{2+}$ at peak $A_{\mathrm{D}}^{\prime}$; if the $\left(\mathrm{C}_{5} \mathrm{H}_{5}\right)_{2} \mathrm{~W}(\mathrm{CO}) / \mathrm{CO}$ reaction system is oxidized at peak $A_{\mathrm{M}}^{\prime}$, i.e., at a potential of ca. $-0.6 \mathrm{~V}$, the subsequent reduction sweep produces only traces of the secondary reduction peak $B_{\mathrm{D}}$ (see Fig. 3), while the pronounced occurrence of the dicarbonyl reduction peaks $D_{\mathrm{D}}$ and $E_{\mathrm{D}}$ indicates a clean conversion to the neutral dicarbonyl complex, in accord with equations 9 and 10. If such a reaction system, containing $0.075 \mathrm{mmol}\left(\mathrm{C}_{5} \mathrm{H}_{5}\right)_{2} \mathrm{~W}(\mathrm{CO})$, is subjected to electrolysis at $-0.6 \mathrm{~V}$ for about $30 \mathrm{~min}$ under $\mathrm{CO}$ its cyclovoltammo- 


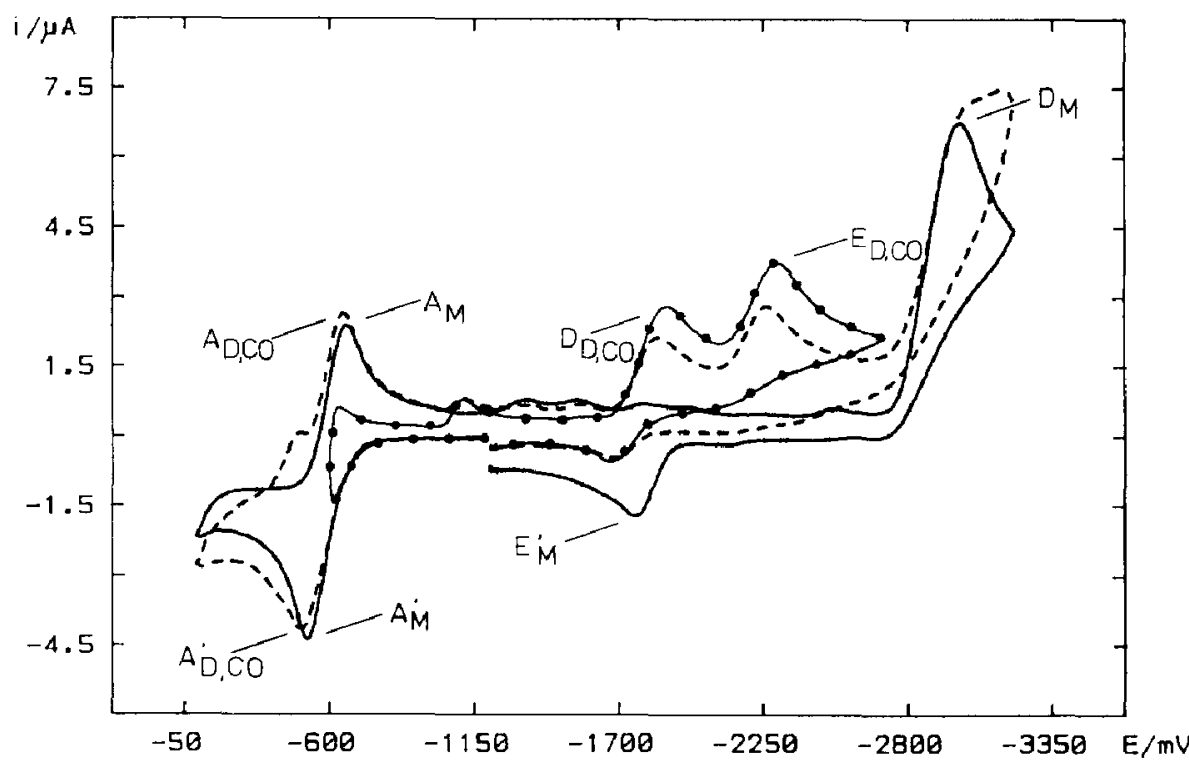

Fig. 4. Cyclic voltammograms of $\left(\mathrm{C}_{5} \mathrm{H}_{5}\right)_{2} \mathrm{Mo}(\mathrm{CO}), 1 \times 10^{-3} \mathrm{M}$ in THF; other conditions as in Fig. 3.

grams are identical to those of a solution of authentic $\left(\mathrm{C}_{5} \mathrm{H}_{5}\right)_{2} \mathrm{~W}(\mathrm{CO})_{2}$, including an entirely reversible oxidation wave $A_{\mathrm{D}}^{\prime} / A_{\mathrm{D}}$. At the end of this electrolysis, which is indicated by a distinct decrease in current, the solution acquires the clear blue colour of $\left(\mathrm{C}_{5} \mathrm{H}_{5}\right)_{2} \mathrm{~W}(\mathrm{CO})_{2}$. The charge of $0.39 \mathrm{C}$ consumed during this electrolysis corresponds to $5.5 \%$ of that required for a total oxidation of $\left(\mathrm{C}_{5} \mathrm{H}_{5}\right)_{2} \mathrm{~W}(\mathrm{CO})$ according to eq. 1 . The electron transfer catalysis represented by eq. 9 and 10 would thus have a coulombic efficiency of 18 molecules of $\left(\mathrm{C}_{5} \mathrm{H}_{5}\right)_{2} \mathrm{~W}(\mathrm{CO})_{2}$ per monocarbonyl cation generated.

4. Related observations on the reaction $\left(\eta^{5}-\mathrm{C}_{5} \mathrm{H}_{5}\right)_{2} \mathrm{Mo}(\mathrm{CO})+\mathrm{CO} \rightarrow\left(\eta^{3}-\mathrm{C}_{5} \mathrm{H}_{5}\right)\left(\eta^{5}-\right.$ $\left.\mathrm{C}_{5} \mathrm{H}_{5}\right) \mathrm{Mo}(\mathrm{CO})_{2}$. While the molybdenocene dicarbonyl complex $\left(\mathrm{C}_{5} \mathrm{H}_{5}\right)_{2} \mathrm{Mo}(\mathrm{CO})_{2}$ has not yet been isolated (and may be too unstable to be isolated) IR evidence for its occasional occurrence in reaction mixtures containing $\left(\mathrm{C}_{5} \mathrm{H}_{5}\right)_{2} \mathrm{Mo}(\mathrm{CO})$ and an excess of $\mathrm{CO}$ has previously been reported [2]. We thus tried to establish whether this dicarbonyl complex is also formed by electrooxidation of the monocarbonyl compound.

Cyclovoltammograms of $\left(\mathrm{C}_{5} \mathrm{H}_{5}\right)_{2} \mathrm{Mo}(\mathrm{CO})$ in $\mathrm{THF}$ solution at $0^{\circ} \mathrm{C}$, under an $\mathrm{Ar}$ atmosphere, give rise to a practically reversible oxidation wave with a standard reduction potential of $-0.61 \mathrm{~V}$ and to an irreversible reduction wave of around $-3.0 \mathrm{~V}$ (Fig. 4$)^{*}$.

The oxidation wave $A_{\mathrm{M}} / A_{\mathrm{M}}\left(E_{\mathrm{P}}\left(A_{\mathrm{M}}^{\prime}\right)=-0.53 \mathrm{~V}, E_{\mathrm{P}}\left(A_{\mathrm{M}}\right)=-0.65 \mathrm{~V}\right.$ at 0.5 $\mathrm{V} / \mathrm{s})$ has a peak separation of ca. $140-150 \mathrm{mV}$ and a peak current ratio of $i_{\mathrm{P}}\left(A_{\mathrm{M}}\right) / i_{\mathrm{P}}\left(A_{\mathrm{M}}^{\prime}\right)=\approx 1$ at a sweep rate of $1 \mathrm{~V} / \mathrm{s}$; at lower sweep rates this peak current ratio is somewhat diminished, e.g. to 0.7 at $0.1 \mathrm{~V} / \mathrm{s}$. As with $\left(\mathrm{C}_{5} \mathrm{H}_{5}\right)_{2} \mathrm{~W}(\mathrm{CO})^{+}$, the life time of the monocation $\left(\mathrm{C}_{5} \mathrm{H}_{5}\right)_{2} \mathrm{Mo}(\mathrm{CO})^{+}$appears to be limited; in contrast

* An additional, broad and irreversible oxidation peak $C_{M}^{\prime}$ appears at the more positive potential of $+0.35 \mathrm{~V}$ 
to the former, however, no secondary reduction peak corresponding to peak $B_{\mathrm{M}}$ is discernible for the molybdenum system.

The irreversible reduction wave at a rather low potential $\left(E_{\mathrm{P}}\left(D_{\mathrm{M}}\right)=-2.97 \mathrm{~V}\right.$ at $0.5 \mathrm{~V} / \mathrm{s}$ ) is again very similar (not only in its oversized peak current but also in respect of its position, peak current and sweep-rate dependence of secondary reoxidation peaks) to that of $\left(\mathrm{C}_{5} \mathrm{H}_{5}\right)_{2} \mathrm{~W}(\mathrm{CO})$, so that the discussion of possible consecutive electron-transfer and chemical decay reactions for the latter species also applies here.

Cyclovoltammograms obtained under a $\mathrm{CO}$ atmosphere also show rather similar indications of the formation of the dicarbonyl complex $\left(\mathrm{C}_{5} \mathrm{H}_{5}\right)_{2} \mathrm{Mo}(\mathrm{CO})_{2}$, induced by the generation of $\left(\mathrm{C}_{5} \mathrm{H}_{5}\right)_{2} \mathrm{Mo}(\mathrm{CO})^{+}$. The diminuation of oxidation peak $A_{\mathrm{M}}^{\prime}$ and the appearance of a second oxidation peak $A_{\mathrm{D}}^{\prime}$ at a slightly more positive potential $\left(E_{\mathrm{P}}\left(A_{\mathrm{D}}^{\prime}\right)=-0.50 \mathrm{~V}, E_{\mathrm{P}}\left(A_{\mathrm{D}}\right)=-0.63 \mathrm{~V}\right.$, at $0.5 \mathrm{~V} / \mathrm{s}$ ) (increasingly evident at lower sweep rates and practically complete in a second sweep cycle) and the growth of a characteristic doublet of reduction peaks $D_{\mathrm{D}}$ and $E_{\mathrm{D}}\left(E_{\mathrm{P}}\left(D_{\mathrm{D}}\right)=-1.96 \mathrm{~V}\right.$, $E_{\mathrm{P}}\left(E_{\mathrm{D}}\right)=-2.33 \mathrm{~V}$ at $0.5 \mathrm{~V} / \mathrm{s}$ ) all duplicate the observations made for the corresponding tungstenocene system. These changes induced by an excess of $C O$ leave no reasonable doubt that the dicarbonyl complex arises through CO-uptake by $\left(\mathrm{C}_{5} \mathrm{H}_{5}\right)_{2} \mathrm{Mo}(\mathrm{CO})^{+}$(eq. 11) and subsequent electron-transfer from $\left(\mathrm{C}_{5} \mathrm{H}_{5}\right)_{2} \mathrm{Mo}(\mathrm{CO})$ to $\left(\mathrm{C}_{5} \mathrm{H}_{5}\right)_{2} \mathrm{Mo}(\mathrm{CO})_{2}^{+}$(eq. 12).

$\left(\mathrm{C}_{5} \mathrm{H}_{5}\right)_{2} \mathrm{Mo}(\mathrm{CO})^{+}+\mathrm{CO} \rightarrow\left(\mathrm{C}_{5} \mathrm{H}_{5}\right)_{2} \mathrm{Mo}(\mathrm{CO})_{2}^{+}$

$\left(\mathrm{C}_{5} \mathrm{H}_{5}\right)_{2} \mathrm{Mo}(\mathrm{CO})_{2}^{+}+\left(\mathrm{C}_{5} \mathrm{H}_{5}\right)_{2} \mathrm{Mo}(\mathrm{CO}) \rightarrow\left(\mathrm{C}_{5} \mathrm{H}_{5}\right)_{2} \mathrm{Mo}(\mathrm{CO})_{2}+\left(\mathrm{C}_{5} \mathrm{H}_{5}\right)_{2} \mathrm{Mo}(\mathrm{CO})^{+}$

There is a pronounced difference from the tungstenocene system, however, in respect of the reversibility of these two oxidation peaks: whereas the conjugate reduction peaks were almost totally absent, in the $\left(\mathrm{C}_{5} \mathrm{H}_{5}\right)_{2} \mathrm{~W}(\mathrm{CO}) / \mathrm{CO}$ reaction system, particularly at higher sweep rates, in the present case there is almost completely reversible, albeit kinetically somewhat hindered, generation of $\left(\mathrm{C}_{5} \mathrm{H}_{5}\right)_{2} \mathrm{Mo}(\mathrm{CO})_{2}{ }^{2+}$ in the $\mathrm{CO}$-saturated solutions. Whatever reactions caused reduction peaks $A_{\mathrm{M}}$ and $A_{\mathrm{D}}$ to disappear in solution containing both $\left(\mathrm{C}_{5} \mathrm{H}_{5}\right)_{2} \mathrm{~W}(\mathrm{CO})^{+}$, and $\left(\mathrm{C}_{5} \mathrm{H}_{5}\right)_{2} \mathrm{~W}(\mathrm{CO})_{2}{ }^{2+}$ seem not to operate for their molybdenum congeners.

After electrolysis of a $\left(\mathrm{C}_{5} \mathrm{H}_{5}\right)_{2} \mathrm{Mo}(\mathrm{CO})$ solution under a $\mathrm{CO}$ atmosphere at -0.6 $\mathrm{V}$, the only peaks observed are those assigned above to the dicarbonyl complex $\left(\mathrm{C}_{5} \mathrm{H}_{5}\right)_{2} \mathrm{Mo}(\mathrm{CO})_{2}$, which thus appears to be capable of extended existence, at least under an atmosphere of $\mathrm{CO}$.

5. Infrared studies at elevated $\mathrm{CO}$ pressures. Exposure of a toluene solution of $\left(\mathrm{C}_{5} \mathrm{H}_{5}\right)_{2} \mathrm{~W}(\mathrm{CO})(0.05 \mathrm{M})$ to $\mathrm{CO}$ pressures up to 120 bar does not cause any decrease in the monocarbonyl adsorption band at $1910 \mathrm{~cm}^{-1}$ or any other change in the IR spectrum indicative of the formation of the tungstenocene dicarbonyl complex. If the toluene solution of the monocarbonyl complex is first treated with $10 \mathrm{~mol} \%$ of $\mathrm{I}_{2}$, however, subsequent exposure to 120 bar of $\mathrm{CO}$ leads to a slow decay of the monocarbonyl adsorption and a concomitant rise of the IR absorption bands of the dicarbonyl complex at 1945 and $1860 \mathrm{~cm}^{-1}$; at $15^{\circ} \mathrm{C}$ this process requires about 2 days for completion. In addition, a broad band at $1981 \mathrm{~cm}^{-1}$ grows in these 


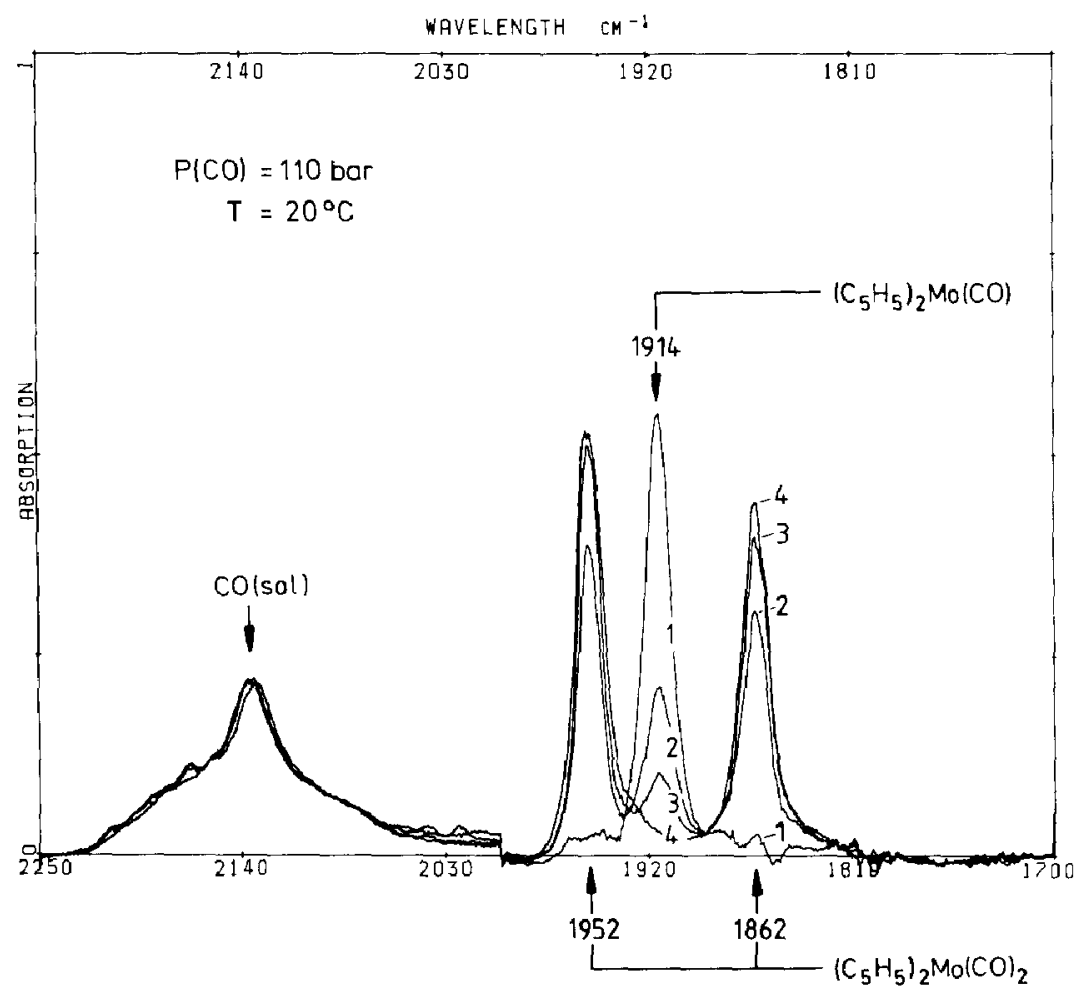

Fig. 5. IR spectra of a $5 \times 10^{-2} M$ toluene solution of $\left(\mathrm{C}_{5} \mathrm{H}_{5}\right)_{2} \mathrm{Mo}(\mathrm{CO})$ at $20^{\circ} \mathrm{C}$ under 110 bar of $\mathrm{CO}$ (after subtraction of solvent spectrum) before (1) and after addition of $10 \mathrm{~mol}-\% \mathrm{I}_{2}$ and subsequent reaction times of $20 \mathrm{~min}(2), 1 \mathrm{~h} \mathrm{(3)}$ and $20 \mathrm{~h}$ (4).

solutions probably owing to the generation of $\left[\left(\mathrm{C}_{5} \mathrm{H}_{5}\right) \mathrm{W}(\mathrm{CO})_{3}\right]_{2}$, the main absorption of which occurs in this region [18].

Subsequent removal of the CO pressure and flushing with $\mathrm{N}_{2}$ gas leaves these dicarbonyl adsorptions unchanged. Evaporation of the reaction mixture and subsequent sublimation yields the dark blue tungstenocene dicarbonyl complex.

Analogous experiments with toluene solutions of $\left(\mathrm{C}_{5} \mathrm{H}_{5}\right)_{2} \mathrm{Mo}(\mathrm{CO})$ again show its complete resistance to 120 bar of $\mathrm{CO}$ in the absence of oxidants. Addition of $\mathrm{I}_{2}$ at a ratio of 1 mol-\% causes a very slow, at $10 \mathrm{~mol}-\%$ a rather fast formation of $\left(\mathrm{C}_{5} \mathrm{H}_{5}\right)_{2} \mathrm{Mo}(\mathrm{CO})_{2}$ with $\nu(\mathrm{CO})$ at 1952 and $1862 \mathrm{~cm}^{-1}$, which is complete in about 3 h. The reaction appears quite clean and no additional IR peaks are discernible (Fig. 5).

Release of $\mathrm{CO}$ pressure from the IR cell and subsequent flushing with $\mathrm{N}_{2}$ does not regenerate the monocarbonyl species; when, however, the contents of the cell were transferred to a Schlenk vessel with exclusion of air, evaporated to dryness and taken up in pentane solution, the IR spectrum indicated a partial regeneration of the molybdenocene monocarbonyl complex.

\section{Conclusions}

The results of the IR studies at elevated $\mathrm{CO}$ pressure leave no doubt that there is no direct $\mathrm{CO}$ uptake by $\left(\mathrm{C}_{5} \mathrm{H}_{5}\right)_{2} \mathrm{Mo}(\mathrm{CO})$ and $\left(\mathrm{C}_{5} \mathrm{H}_{5}\right)_{2} \mathrm{~W}(\mathrm{CO})$. In this regard, these 


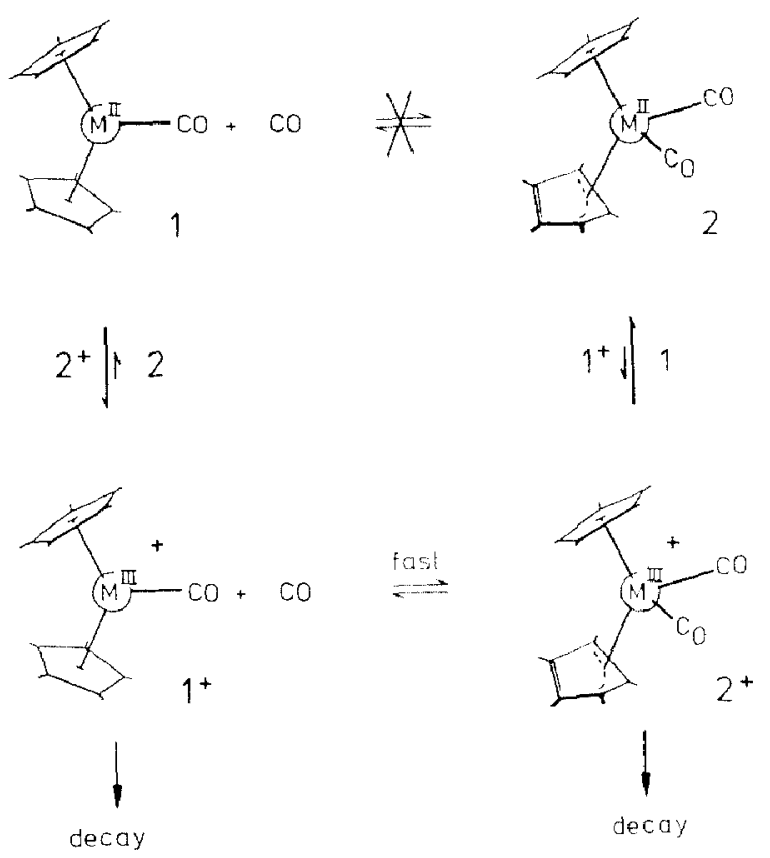

Scheme 1

two metallocene carbonyl reaction systems differ from their chromocene analogue, where a slow but finite rate of conversion to the dicarbonyl complex was observed even at $-30^{\circ} \mathrm{C}[7]$.

As noted before with the ansa-chromocene derivatives, oxidation of the molybdenocene and tungstenocene monocarbonyl complexes to their respective monocations induces a rapid $\mathrm{CO}$ uptake. From the $\mathrm{CV}$ data we estimate that these reactions have a half-life of the order of $1 \mathrm{~s}$ for $\left(\mathrm{C}_{5} \mathrm{H}_{5}\right)_{2} \mathrm{~W}(\mathrm{CO})^{+}$and $0.03 \mathrm{~s}$ for $\left(\mathrm{C}_{5} \mathrm{H}_{5}\right)_{2} \mathrm{Mo}(\mathrm{CO})^{+}$, in THF solutions saturated with 1 bar of $\mathrm{CO}$. The chain-carrying species appear to be the monocarbonyl and dicarbonyl monocations, the redox potentials of these species being suitable for an efficient electron-transfer catalysis *.

Our studies have shown that both of these $W^{111}$ cations are susceptible to degradation; the resulting species, e.g. that reduced at peak $B_{\mathrm{D}}$, appear to be less suitable, by virtue of their rather low reduction potentials, to oxidize the monocarbonyl species. The very low rate of conversion of the monocarbonyl to the dicarbonyl complexes induced by oxidation with $I_{2}$ has 10 be regarded as a consequence of the preponderant presence of some $\mathrm{M}^{\mathrm{iV}}$ species such as $\left(\mathrm{C}_{5} \mathrm{H}_{5}\right)_{2} \mathrm{M}(\mathrm{CO}) \mathrm{I}^{+}$, which by redox comproportionation with $\left(\mathrm{C}_{5} \mathrm{H}_{5}\right)_{2} \mathrm{M}(\mathrm{CO})$ would probably generate only minute quantities of the crucial species $\left(\mathrm{C}_{5} \mathrm{H}_{5}\right)_{2} \mathrm{M}(\mathrm{CO})^{*}$.

Likewise, the stability of $\left(\mathrm{C}_{5} \mathrm{H}_{5} \mathrm{O}_{2} \mathrm{~W}(\mathrm{CO})_{2}\right.$ against loss of $\mathrm{CO}$, even under sublimation conditions, appears to be a consequence of this instability of both $\left(\mathrm{C}_{5} \mathrm{H}_{5}\right)_{2} \mathrm{~W}(\mathrm{CO})^{+}$and $\left(\mathrm{C}_{5} \mathrm{H}_{5} \mathrm{O}_{2} \mathrm{~W}(\mathrm{CO})_{2}^{+}\right.$monocations. without the catalytic intervention of which $\mathrm{CO}$ loss from the dicarbonyl complex must be inhibited as effectively as CO uptake by the monocarbonyl species.

* For a recent review on electron-transfer catalysed ligand-exchange reactions see ref. 19. 


\section{Acknowledgments}

Financial support by the Deutsche Forschungsgemeinschaft (grants Bri 510 and $\mathrm{Ki}$ 294), by the Fonds der Chemischen Industrie and by the funds of the University of Konstanz is gratefully acknowledged.

\section{References}

1 J.M. O'Connor and C.P. Casey, Chem. Rev., 87 (1987) 307.

2 K.L.T. Wong and H.H. Brintzinger, J. Am. Chem. Soc., 97 (1975) 5143.

3 L.G. Bell and H.H. Brintzinger, J. Organomet. Chem., 135 (1977) 173.

4 G. Huttner, H.H. Brintzinger, L.G. Bell, P. Friedrich, V. Bejenke and D. Neugebauer, J. Organomet. Chem., 145 (1978) 329.

5 M.L.H. Green, private communication.

6 E.U. van Raaij, S. Mönkeberg, H. Kiesele and H.H. Brintzinger, J. Organomet. Chem., in press.

7 E.U. van Raaij and H.H. Brintzinger, J. Organomet. Chem., in press.

8 F.W.S. Benfield, B.R. Francis and M.L.H. Green, J. Organomet. Chem., 44 (1972) C13; J.L. Thomas and H.H. Brintzinger, J. Am. Chem. Soc., 94 (1972); J.L. Thomas, ibid., 95 (1973) 1838.

9 R.L. Cooper and M.L.H. Green, J. Chem. Soc. A, (1967) 1155; M.L.H. Green and P.J. Knowles, J. Chem. Soc. Perkin I, (1973) 989.

10 H. Kiesele, Anal. Chem., 53 (1981) 1952.

11 W. Tritschler, Dissertation, Universität Konstanz 1986.

12 H. Schwemlein, W. Tritschler, H. Kiesele and H.H. Brintzinger, J. Organomet. Chem., 293 (1985) 353.

13 G. Milazzo and S. Caroli, Tables of Standard Electrode Potentials, New York 1978, p. 322.

14 E.U. van Raaij, C.D. Schmulbach and H.H. Brintzinger, J. Organomet. Chem., 328 (1987) 275.

15 D.S. Polcyn and I. Shain, Anal. Chem., 38 (1966) 370.

16 J. Crank and P. Nicolson, Proc. Cambr. Phil. Soc., 43 (1947) 50; G.D. Smith, Numerical Solution of Partial Differential Equations, Oxford, 1969; D. Britz, Digital Simulation in Electrochemistry, 2nd edition, Berlin 1987.

17 K.M. Kadish, D.A. Lacombe and J.E. Anderson, Inorg. Chem., 25 (1980) 2246.

18 T. Madach and H. Vahrenkamp, Z. Naturforsch. B, 34 (1979) 573; Chem. Ber., 113 (1980) 2675.

19 D. Astruc, Angew. Chem., 100 (1988) 662. 